\title{
Leisure as a Field of Study in Higher Education
}

\author{
KAS MAZUREK* and DON DAWSON†
}

\begin{abstract}
Leisure Studies is an emerging field of study in higher education, which is engaged in a struggle for academic legitimacy in Canada and elsewhere. The field and its research endeavours can be said to be characterized by a lack of paradigmatic maturity which may best be resolved by the philosophical questioning of the fundamental principles underlying its discourse. Toward this end, a metaphysics of leisure study is urged. In this way, a distinct identity for the field may develop. Leisure Studies, finally, is not an academic "discipline", but rather a multidisciplinary field of study distinguished by its substantive area of inquiry. The present paper is most directly a commentary on the state of Leisure Studies and research in Canadian universities, but many of its observations apply to the U.S.A. and Britain as well.
\end{abstract}

\section{RÉSUMÉ}

Les sciences du loisir en tant que champ d'étude émergeant doivent lutter afin d'assurer leur légitimité académique à l'enseignement supérieur tant au Canada que dans d'autre pays. Ce domaine est à la recherche d'un paradigme que le questionnement philosophique des principes fondamentaux soustendant son discours pourrait aider à définir. A cette fin, une métaphysique des sciences $d u$ loisir se fait urgente, ce qui permettrait le développement d'une identité propre à ce domaine. Les sciences du loisir, enfin, ne sont pas une discipline mais plutôt un domaine d'étude multidisciplinaire se démarquant par un domaine d'enquête indépendant. Cet article présentera un commentaire sur la situation des sciences du loisir et de la recherche dans les universités canadiennes; de nombreuses remarques et observations s'appliqueront aussi bien aux États-Unis qu'en Grande-Bretagne. 


\section{LEISURE STUDIES?}

The field of "Leisure Studies" in Canada and around the world is presently undergoing growing pains which are inevitable in the evolution of a new program of study and field of inquiry in the academic community. As one might expect, some members of the established disciplines have ridiculed this new, ersatz tenant of the Ivory Tower. It must be noted, however, that the social sciences in general have only themselves recently gained credibility and acceptance as "legitimate" disciplines. While some Canadian scholars (Burton 1984) proclaim that leisure is an increasingly accepted field of study in academia, Leisure Studies is still far from being widely embraced and continues to be the target of sometimes acerbic cynicism, in which it is treated as an unwanted interloper on the university scene.

For example, in an open letter to the Canadian Association of University Teachers, Engineering professor Carl Goldman (1984: 2) asked the following: "Why are many universities flooded with mickey-mouse courses? It is embarrassing to list these courses, but does Recreation and Leisure Studies belong in a University?" Also, there is the unkind commentary from another Canadian observer, J.E.G. Dixon (1985: 30), who gleefully lampoons the unfortunate neologism "recreology":

The recreologists follow the precedent of the museologists, that is, the students of museums, who took it upon themselves to add distinction to their study, by adding a learned suffix to their name. One wonders why they didn't prefer museumology, or recreationology. On the contrary, the sham will serve only to bring ridicule upon them for their pretension.

This, however is merely a prolegomenon for a more fundamental critique of recreation and leisure studies. Dixon (1985: 30) asserts that higher learning, scholarship, and the pursuit of truth are the traditional occupations of the university, and that "recreational studies have nothing whatsoever in common with higher learning." One final warning comes from Dixon's (1985: 30) vitriolic pen: "the greatest danger lies in the possibility that these imposters [such as] recreology will actually come to be considered equal to philosophy."

Such disdain for one's academic colleagues is remarkable indeed. One can hardly imagine such a diatribe against physics or history. One cannot, however, dismiss the detractors of leisure studies with semantic distinctions between recreation and "recreology," or "Leisure Studies," or even "Leisure Sciences." Yet, a large part of the quest for acceptance is endurance, a waiting game. For example, the "new" discipline of sociology is accepted today partly because it is no longer "new". The passing of the post-war decades has brought sociologists acceptance (sometimes reluctant) and even respectability (often grudging) in academic quarters. As one inside observer of Canadian sociology has remarked (Synnott 1986: 5), "Departments of sociology ... have been described in different ways by different people: as ivory towers, zoos, circuses, battlefields, even as a joke." Certainly one would not want to suggest that sociologists have merely outlived their detractors, but those engaged in Leisure Studies can take heart in the 
prospect that, in the end, their field may, as have other once "new" fields of study, secure at least some measure of peaceful co-existence.

Historically, studies of leisure have been going on for at least several decades in Canada and U.S.A. One finds, for example, a spate of sociological studies of leisure appearing in the American Sociological Review and the American Journal of Sociology during the middle 1950s (see among others, Reissman 1954; White 1955; Clark 1956; Havighurst 1957). More recently a considerable amount of work which deals with leisure phenomena has been undertaken within the predominantly British "cultural studies tradition" (see, for example, Hall \& Jefferson 1976; Bennett, Martin, Mercer \& Woolacott 1981), and by social historians (see, for example, Bailey 1978; Cunningham 1980).

Today there remain some persistent differences between the U.S.A. and Britain in the study of leisure. Notwithstanding the work of American sociologists in the 1950s, many scholars presently working in American universities have arisen out of professionally oriented programs such as Park and Recreation Resource Management. As a result, the American Leisure Studies field is dominated by those primarily interested in the delivery of recreation services. In general, these services may be classified under four broad categories; (1) recreation program planning, (2) recreation administration, (3) therapeutic recreation (for the disabled, etc.), and (4) outdoor recreation (e.g., ecology and conservation). Consequently, Leisure Studies curricula in the U.S.A. have tended to emphasize the teaching of practical skills and abilities required of professionals providing leadership in the various facets of recreation and leisure. Leading leisure educators in American universities have, however, recently drawn attention to what they perceive to be the growing separation of the more academically-focussed, theoretically-based, and research-oriented Leisure Studies programs from traditional Park and Recreation education (see Burdge 1985).

In Britain, on the other hand, those who have come into prominence in Leisure Studies have typically not come from a professional park and recreation background, but rather have emerged from diverse fields such as industrial sociology and the critical "cultural studies" area. The British approach, then, has from the outset been somewhat more theoretically informed and has tended to investigate leisure as a social phenomenon more so than as a social service. Of course, there are some professional programs of Recreation Management in British universities and polytechnics, but for the most part these programs are more recent and less numerous than one finds in the U.S.A.

It remains, however, that until recently the study of leisure in Canada has been episodic. A primary cause of this slow evolution of leisure as a distinctive, ongoing area of study has been the "inability of the field to attract a sufficiently large 'critical mass' of active researchers" (Gruneau 1983: 3). Such is no longer the case. The International Directory of Academic Institutions in Leisure, Recreation and Related Fields (D'Amours 1986) contains over 1,000 entries from 42 nations. In Canada today there are some 20 universities offering a variety of programs in recreation and leisure. Of these programs, there are at least 10 
Bachelor's degree programs, five Master's programs and one Doctoral program whose central theme is the study of leisure. Within these programs, however, there is a tremendous diversity of approaches to the study of leisure. Some programs are more concerned, for example, with the study of the management of recreation systems, including municipal and outdoor recreation, rather than the study of leisure as a social phenomenon in everyday life.

Regardless of the current orientations of the various programs, Burton (1984: 2-3) holds that the evolution of Leisure Studies in higher education in Canada reflects three primary influences:

The first and strongest influence has come from the field of health and physical education. The majority of formal recreation degree and certificate programs has emerged from health and physical education curricula. The second influence has come from fields whose primary concern has been the planning and management of recreation resources - geography, urban planning, forest science, business administration, and related fields. The final influence has come from the humanities and social sciences. There has always been a strong liberal education component to recreation and leisure studies in Canada and this has been reinforced within the past decade or so by a concentration on the contributions of the social sciences to an understanding of the significance and roles of recreation and leisure in Canadian society.

Thus, at present there exists a variety of programs of studies in recreation and leisure throughout Canadian universities from coast to coast. Degrees offered range from a number of Bachelor in Physical Education degrees with specialization in Recreation, to several Bachelor of Outdoor Recreation degrees, some Bachelor of Education degrees with a recreation component, and a few Bachelor of Recreation and Leisure or Bachelor of Leisure Studies degrees. Many programs offer a cooperative component which integrates practical work experience within an academic course of studies. Graduates of Leisure Studies programs from Canadian universities are found working in diverse settings which include hospitals, private service agencies, industry, municipalities, school boards, national and provincial parks, voluntary associations, youth services, geriatric services, and provincial or federal governments. As of the 1983-1984 academic year, there were some four thousand students persuing degrees in Leisure Studies at Canadian Universities (D'Amours 1986: 223). Moreover, the numbers of both students and programs are growing every year.

\section{PARADIGMATIC UNITY?}

Another factor in the attainment of acceptance by the academic community of Leisure Studies is ultimately more significant than the "newness" of the field. It is sometimes the case that the perceived legitimacy of a field of academic endeavour is proportional to the ability of researchers, employing diverse methodologies within that field, to coordinate their studies and methods under the umbrella of an encompassing paradigm. The clearest insight into this process is provided by Thomas Kuhn in the Structure of Scientific Revolutions. Following Kuhn, it can be 
said that Leisure Studies in Canada and elsewhere may be at the "preparadigmatic" stage of evolution. Such a stage is characterized by "a number of competing schools and subschools" wherein "different men confronting the same range of phenomena ... describe and interpret them in different ways" (Kuhn 1970: $12,17)$.

The suggestion is that one must focus upon the degree to which Leisure Studies is falling short of being a cohesively articulated field of study. It is important to consider the extent to which researchers and teachers in Leisure Studies are or are not "committed to the same rules and standards for practice" (Kuhn 1970: 11). At present, it appears that there are a variety of schools of thought on what ought to constitute the practice of Leisure Studies (see Burdge 1985; Godbey 1985; Smith 1985). Indeed, it is questionable if there is consensus on what entails the accepted range of phenomena appropriate to the study of leisure.

Conceived thus, one begins to appreciate how many of the wounds of Leisure Studies are self-inflicted. The question "What is Leisure Studies?" is a legitimate one because scholars within that field are themselves in disagreement as to the answer. As long as this situation pesists among Leisure Studies scholars, it may be an obstacle to the progress of the field as a whole. Equally, there can be little success in having other disciplines understand the nature and the method of this field of study.

Conversely, obvious objections can be immediately and legitimately raised. First, why not simply wait and let a dominant paradigm emerge? This will indeed ultimately come about as a sort of intellectual Social Darwinism eventually prevails. However, as Kuhn warns, the best ideas and methods do not necessarily come to predominate. Academia, like any other social organization, is susceptible to interest group politics. The hope that "truth" or the "one best method" will win is naive. The largest departments with the most prolific professors and the greatest number of graduate students have an uneven advantage in the dissemination of particular intellectual orientations. Canadian sociologists and anthropologists, for example, have secured a place in academia by virtue of their ability to attract "vast numbers of students to their disciplines, and achieving fame, influence, power as well as notoriety" (Synnott 1986: 5). Such is the law of the academic jungle.

Second, one may question the need for a single, ubiquitous paradigm. Is the imperative of strengthening the field of Leisure Studies within the academic community so great that its practitioners are willing to circumscribe their own intellectual licence? Must the rich diversity of scholarship within this multifacetted field be suppressed? It is perfectly acceptable, indeed desirable, to have diversity of method. To return to the two noted disciplines of physics and history, we may note many paradigmatic debates. The polarization of physicists into Einsteinian and Heisenbergian camps is a cleavage characteristic of modern science. Historical theory and practice is fragmented into camps of quantitative historians, whig historians, psycho-historians, social historians, revisionists, ad infinitum. Yet the academic credibility of physics and history, as legitimate and viable disciplines, is unquestioned. 
There is, therefore, no overwhelming reason to demand rigid conformity to one paradigm; Leisure Studies may have several. There is, however, a demand that such paradigms be clearly and consciously articulated. It is essential, then, that practitioners first recognize that they in fact are practising within paradigms. This may be the central deficiency within the field of Leisure Studies today. Rather than contributing to the articulation of a clear paradigm or paradigms, some Canadian scholars in Leisure Studies appear to have "borrowed" methodologies and concepts from many disciplines on an ad hoc basis, seemingly with little regard for whence they came. As Goodale and Witt (1980: 298) point out, the "applied research" and "pragmatic problem solving" which have dominated Leisure Studies "may not yield the theoretical knowledge base necessary for the development of a strong discipline."

This discussion of the paradigmatic immaturity of Leisure Studies ends on a somewhat contradictory note. It is held that the absence of a clearly dominant paradigm has contributed to the weakness of the Leisure Studies field in Canada. Indeed, as Gruneau (1983: 5) points out, the "institutionalization" of a field of study as a "bona fide academic discipline" requires a "careful delimination of [its] specific frames of reference." On the other hand, we assert that it is not necessary to demand conformity to one overarching paradigm. What is necessary, and not contradictory, is that narrow intramural debates be put aside, and that researchers in the field become conscious of and clearly articulate what are the major competing de facto paradigms in Leisure Studies (see Rojek 1985 for a good first effort in this area).

\section{A METAPHYSICS OF LEISURE?}

The ensuing "legitimation crisis" in Leisure Studies is a crisis of articulation. This is a consequence of the seeming reticence of many in the field to come to grips with the content(s), structure(s), and method(s) of Leisure Studies. Sebastian de Grazia (1964: 6-7) recognized this some time ago: "It becomes increasingly clear that the perspectives called for ... uses many methods and takes the many findings of the many pertinent sciences to bring them together, and does not hesitate to ask fundamental questions if they seem to the point - the perspective is that of the political philosophy of leisure." Hence, the remedy to the present disarray in Leisure Studies is the conscious examination of fundamental philosophical questions, a concentration upon what may be termed the "Metaphysics of Leisure Studies." Concern with such a question is not an esoteric endeavour. It is a conscious attempt to build a solid foundation for the field. At least three basic types of questions must be addressed - the ontological, espistemological, and praxiological.

Ontological questions necessary to the metaphysics of Leisure Studies are those that address our perception of the ultimate nature of mankind. These questions are primary in that the human being is the starting point for all the humanities and social sciences. Epistemological questions address how the inquiry into our subject matter should proceed. These questions concern how we come to know our 
subject matter as well as the problems and obstacles in the way of our inquiry. Praxiological questions deal with the application of our perceptions of and mode of inquiry into human and social reality, and form the basis for empirical and existential attempts to validate our perceptions in the realm of applied research and policy formulation.

Obviously, all three kinds of questions are inter-related. Furthermore, such a conscious three-dimensional investigation has been employed by some of the earliest students of leisure. To Aristotle, leisure was a "first principle," a precondition for being human. In their haste to draw upon such an eminent authority, scholars in Leisure Studies have sometimes forgotten (as Aristotle did not) that the nature of the human animal (ontology) must be laboriously and meticulously investigated (epistemology) to serve as a guide to the development and refinement of social practices (praxiology), which must in turn lie in congruence with human nature and the limitations of our knowledge of human nature and society. It is not sufficient simply to quote Aristotle's maxim that "leisure is the absence of the necessity of being occupied;" the fundamental assumptions which lead to this position must be investigated.

The appropriation of Aristotle's thought to answer fundamental philosophical questions concerning leisure and its study has proven treacherous. Translators of Aristotle note that his use of the term "leisure" is one of the most difficult to translate into present modes of thought. In Politics, Aristotle affirmed that the first principle of all action, including work, is leisure, and that leisure is work's end. Thus, "we are unleisurely in order to have leisure." However, according to Aristotle recreation is not of the same order as leisure (Gillis 1886: 360):

Happiness then, cannot consist in mere recreative pastime; for it is absurd to think that all our serious exertions and strenuous labors should terminate in so frivolous an end. We do not labor that we may be idle, but, as Anarchis justly said, we are idle that we may labor with more effect ... The weakness of human nature requires frequent remissions of energy; but these rests and pauses are only the better to prepare us for enjoying the pleasures of activity. The amusements of life, therefore, are but preludes to its business, the place of which they cannot possibly supply; and its happiness, because its business, consisting of the exercise of those virtuous energies which constitute the worth and quality of our nature.

The same appreciation of philosophical method is found in Pieper's Leisure: the Basis of Culture, although with different content and consequence. Like Aristotle, he (Pieper 1965: 86) asked "What kind of a world is man's world? - a question which patently cannot be answered without reference to the nature of man. And in order to achieve some degree of clarity, we must begin from the beginning and start from the bottom."

The answer was clear to Pieper: "Christianity is essentially reality" and "to be a Christian is a qualification of being" (Pieper 1965: 133 passim). This ontological position finds epistemological correspondence in intuition/revelation (Pieper's preferred term is "wonder") and praxiological correspondence in the conduct of life, of leisure, and of culture according to Christian principles. Pieper also held the corollary that leisure is "utterly contrary" to industrial labour in that its genesis 
is found in the spiritual realm, not that of the material. Today Pieper's followers are few but he continues to be read. He is read for his comprehensiveness and for his systematic, integrated articulation of an encompassing perspective on leisure. While the conclusions of both Aristotle and Pieper may not be entirely relevant today (on a praxiological level), their ontological and epistemological approaches remain pertinent and instructive for the current search for identity in Leisure Studies.

Modern "critical" approaches to the study of leisure (see Rojek 1985 for a review) rely largely upon a neo-Marxist ontology, epistemology, and praxiology. The nature of human existence under capitalism is to be discovered, it is argued, in the contradiction inherent in the capitalist class system. The examination of structural contradictions in modern capitalist society will reveal the nature of individual and collective leisure. The praxiology of leisure research and programs must, accordingly, be directed toward the overcoming of alienation and false consciousness within leisure relations. Again, the symbiotic interdependence and correspondence between ontology, epistemology, and praxiology become evident. Of course neo-Marxist critiques of leisure do not exhaust the critical school of leisure thought. Andrew (1981), for example, puts forth an anarchistic view of Leisure Studies. Within this perspective, Andrew condemns both scientific management and technocratic socialism, and proposes anarcho-syndicalism, democratic self-management, and the unity of meaningful work and leisure.

Despite these recent critical approaches to Leisure Studies, it is clear that most Canadian research into leisure to date has ignored critical perspectives. Indeed, Rojek (1985) argues that there is a "submerged tradition in leisure" which is largely descriptive and atheoretical. Research in this tradition most often follows survey methods and is policy-inspired. Moreover, leisure in this view has usually been held to be an inherently progressive force, levelling social inequalities and providing an area of life within which free choice and personal liberty reign. This tradition is not, however, a consciously articulated philosophy, it is an ecclectic, often contradictory, juxtaposition of mutually incompatible assumptions and principles. There is, then, no clear evidence of a dominant paradigm of Leisure Studies and Rojek (1985) is decidedly premature in claiming that there is "multi-paradigmatic rivalry" in the field. There can be no clear rivalry between paradigms until such time as these paradigms are formally articulated by their adherents. Clearly, many involved in leisure research remain either unaware or uninterested in discussing fundamental philosophical questions. On the other hand, a few such as Neulinger (1974), Iso-Ahola (1980), and most recently Kelly (1987) have attempted to clarify these basic questions.

Thus, in order to lay the foundations for Leisure Studies as a distinct area of scholarly inquiry in Canada and elsewhere, the following imperatives must be recognized:

1. the ontological imperative to build the field of Leisure Studies on a clearly articulated notion of human and societal nature; 
2. the epistemological imperative to appreciate that the study of leisure and society is fraught with obstacles and obscurity; and

3. the praxiological imperative to understand that the practice of research on leisure and the formulation of policy is inevitably influenced by ontological and epistemological considerations.

As any review of Leisure Studies in Canada would reveal, however, a number of paradigm-like orientations (some less consciously articulated than others) are presently competing in the field. Some of these were mentioned above. The practical consequences of this competition between quasi-paradigms are at times dramatic. A preoccupation with Aristotelian discourse could result in an abstract orientation which might lead some scholars to neglect the reality of urban, industrialized society (see Andrew 1981:21-23). Pieper's position can be seen as an attempt to model the study of leisure within a Victorian moralistic framework. The neo-Marxists have attempted to reorient Leisure Studies with their focus on the working class leisure experience, on base-superstructure relations between productive activities and leisure, and on leisure as a political sphere of life. Of course, the undercurrent of the submerged tradition in leisure continues despite the incursions of new perspectives.

The examples given above are, in fact, the stuff paradigms are made of, and indicate the role of philosophy in the articulation of Leisure Studies paradigms. Notwithstanding these examples, contemporary Canadian Leisure Studies, as evidenced by its submerged tradition, has tended, in the quest for legitimacy, to back away from such soul-searching debate. Aristotle is too pretentious; Pieper's vision is proselytism; and Marxism is both of these.

What, then, remains for Leisure Studies? What remains is "objectivity," that modern god of social science which in practice often simply means not asking the fundamental questions on which de Grazia insisted. Instead, one merely "borrows" the research methods and the questions for study from other agencies the government, other academic disciplines, and the recreation service profession. This avoidance of intellectual responsibility may have backfired. Rather than legitimizing Leisure Studies in the eyes of the Canadian academic community, opportunistic eclecticism has often resulted in scorn. The unique object and field of study (ontology), the unique examination and articulation of that object and field of study (epistemology), and the unique research and policy formulations resulting from material context and intellectual inquiry (praxiology) are all seen to have been appropriated, ad libitum, from the established disciplines. Consequently, Leisure Studies in this country is seen to be a jerry-built edifice with no unique context(s) or method(s) of its own. It appears that instrumentalism has superseded the philosophical search for paradigmatic maturity in the field of Leisure Studies.

As Burton (1980: 374) suggests, in Canada "leisure research, as a field, has no sense of direction and purpose but consists of many people from many disciplines galloping off in all directions simultaneously." The only commonality is the 
familiar call for objectivity - empiricism, scientific methods, and quantitative techniques. The result is that at least until very recently, Leisure Studies remained dependent upon the parent disciplines for its themes of study as well as its methodological base. Leisure Studies in Canada has emerged, then, as an ill-defined, undisciplined "mish-mash" of approaches and topics. Burton (1980: 382) concludes that "the most important step in the drive to maturity must be the development of an epistemology of leisure, the establishment of a set of unifying concepts and codes for the field." Thus, we may perhaps have more sympathy with the critics' question: "What is Leisure Studies?" They have a point. Perhaps Leisure Studies itself cannot answer this question because it has up till now failed to ask such fundamental questions of itself. The answer, obviously, cannot be discovered through more empirical research and further data collection. What is required is a process of reflexive self-discovery through the development of the philosophical foundations of Leisure Studies. In the meantime, however, there has been considerable debate as to whether or not Leisure Studies constitutes a "scholarly discipline".

\section{LEISURE STUDIES - A DISCIPLINE?}

Burton (1980: 379 ) contends that during the 1960s the field of Leisure Studies in Canada and elsewhere experienced a growth in multidisciplinary approaches:

Instead of each discipline considering leisure issues and concerns in its own unique, distinct and self-contained manner, each began to recognize that its own unique and distinct approach was not self-contained, but exists within a broad context which admits of many equally valid ways of viewing the world. It was increasingly recognized that each of the parent disciplines of leisure research had a valuable contribution to make to the field and, more importantly, that the simultaneous application of several disciplines to an issue or problem might offer insights that each alone could not.

In this way, Burton feels that Leisure Studies is no longer merely the simple sum of independent contributions from the various established disciplines, but in fact is a field of study which transcends disciplinary boundaries. What began as interdisciplinary and multidisciplinary perspectives on leisure have, in this view, evolved to the point where Leisure Studies in Canada has "an emerging disciplinary base of its own" (Burton 1984: 4) with an established, distinct area of study and a growing formal body of knowledge. This sentiment is echoed by other Canadian scholars in the field (Smith 1985: 158): "We are a unique and separate social science.... I submit that our field has developed a cumulative body of knowledge that is identifiably distinct from any other." Indeed, Smith (1985: 155) has heralded "the emergence of leisure studies from a loose confederation of like-minded scholars to one of the newest and most complex autonomous disciplines." These views have not, however, gone unchallenged.

While Burdge (1983) allows that there is a trend towards the creation of "subdisciplines" which break away as new disciplines, and subsequently fight for 
a place within the academic hierarchy of disciplines, he does not believe that Leisure Studies constitutes a genuine scholarly discipline. Sessoms (1984: 332), despite acknowledging that Leisure Studies is "cast in the mold" of the traditional disciplines and that its proponents approach it "as if it were a discipline," expresses similar doubts. Such critics hold that there is no identifiable core of study in the field, no new research methods, and no generic theory. Leisure Studies is not, then, a discipline, but merely a more or less definable topic of study. Moreover, as an applied area (i.e., parks and recreation services), it is lacking the "theoretical integration and methodological vigor" of the established academic disciplines (Burdge 1983: 123). Thus, the study of leisure addresses a "problem" in society, in the same way as do "urban studies," "Canadian studies" or "women's studies." What is required in these areas of study is an interdisciplinary and/or multidisciplinary approach (Burdge 1985). Leisure Studies is such an area of study, and does not constitute a discipline unto itself.

Of course, another very large multidisciplinary field of study which has gained acceptance within the university system is the field of Education itself. Within the field of Education, many researchers employ a variety of disciplinary techniques from psychology, sociology, philosophy, history and others. Thus, many disciplines are at work within the field of Education and Educational Studies is not generally conceived of as comprising a discipline unto itself. Certainly, the field of Leisure Studies may some day come to be seen as somewhat analogous to the study of Education in institutions of higher education.

Godbey (1985: 145) holds that Leisure Studies is not a discipline, but "is, rather, a subject of study." Clearly, with no unique methodology or body of theory to call its own, "there is really no such thing as Leisure Studies in a generic sense" (Godbey 1985: 147). In launching its new journal, Leisure Studies, the British Leisure Studies Association described leisure as a field of study with a mix of subjects and disciplines. The editors (Haworth et al. 1982: iv) of the journal's first issue called for submissions from "the various academic disciplines or quasidisciplines which contribute to leisure studies: economics, human geography, philosophy, psychology, social history, sociology (the list is alphabetical but not exhaustive)." What was to give coherence to the journal of Leisure Studies and, ipso facto, the field of Leisure Studies, was the subject of study. "If it is labelled as leisure, believed to be leisure, or has leisure-like qualities, then it is a suitable subject of study" (Haworth et al. 1982: iv). It is the substantive area of study, not any unique methodological approach nor theoretical perspective which is the glue that holds Leisure Studies together.

Clearly, the field of Leisure Studies is not a discipline but simply (or perhaps not so simply) a field of study. Terms such as "Recreology" are pretentious and inappropriate in that there is the suggestion that the study of leisure has a unique disciplinary basis in the same way as does sociology or psychology. It does not. One can study leisure from, for example, a sociological perspective, employing its methods and theoretical formulations; but one cannot similarly conduct an inquiry into society employing methods and theory constituent of Leisure Studies. 


\section{CONCLUSIONS?}

The present discussion points to several related conclusions. Initially, it must be recognized that leisure as a field of study is engaged in a struggle for legitimacy in academic quarters in Canada and around the world. As was the experience with the social sciences in general, however, such acceptance may be forthcoming in the future. A second conclusion is that Leisure Studies is not a coherently articulated field of study. There are no clear paradigms inherent to the study of leisure, and little consensus exists within the community of scholars interested in the area and engaged in leisure research in Canada. Much more needs to be done in Leisure Studies so as to establish the "first principles" of this field of inquiry; ontological, epistemological and praxiological questions must be addressed. Only in ths way will a distinct identity for the field be developed.

Leisure Studies, finally, is not a discipline sui generis. It is, rather, a multidisciplinary (consisting of many disciplines) field of study that is distinguished not paradigmaticly, but by its substantive area of study, leisure. That this area of study is, in Godbey's (1985: 145) words, "hard to pin down," constitutes the cause of much of that which ails Leisure Studies today. Given this state of affairs, what is the future of Leisure Studies in Canadian universities? What direction should the field take? Where would its programs of study be best situated in the university system?

Initially, it would seem that Canadian Leisure Studies ought to strengthen its academic foundations through renewed emphasis on theory building and research rather than professional development and practical training. Nevertheless, the cooperative programs that presently exist appear to be very successful and should be maintained in order to accommodate the needs of the expanding leisure service labour market. After all, most students enrolled in Leisure Studies programs will be looking for jobs in their chosen field when they graduate. Lastly, while at least one Canadian Department of Leisure Studies is found in a Faculty of Social Sciences, many strong programs are housed in faculties or schools of Physical Education and elsewhere. Thus, as long as teachers and researchers in the field maintain their multidisciplinary approach, there does not seem to be a one "best" location for Leisure Studies within the structure of Canadian universities.

\section{REFERENCES}

Andrew, E. (1981). Closing the iron cage: The scientific management of work and leisure. Montreal: Black Rose.

Bailey, P. (1978). Leisure and class in Victorian England. London: Routledge \& Kegan Paul.

Bennett, T., Martin, G., Mercer, C., \& Woolacott, J. (eds.). (1981). Culture, ideology and social process. London: Batsford.

Burdge, R. (1985). The coming separation of leisure studies from Parks and Recreation education. Journal of Leisure Research 17(2): 133-141.

Burdge, R. (1983). Making leisure and recreation research a scholarly topic: Views of a journal editor, 1972-1982. Leisure Studies 6(1): 99-126. 
Burton, T. (1984). The origins and evolution of recreation and leisure studies in Canada. Submission to the Social Sciences and Humanities Research Council of Canada.

Burton, T. (1980). The maturation of leisure research. In Goodale, T and Witt, P. (Eds). Recreation and Leisure: Issues in an Era of Change. College Circle, Pennsylvania: Venture Pub.

Clark, A.C. (1956). The use of leisure and its relation to levels of occupational prestige. American Sociological Review 21: 301-307

Cunningham, H. (1980). Leisure in the Industrial Revolution. London: Croom Helm.

D'Amours, M. (1986). The international directory of academic institutions in leisure, recreation, and related fields. Ottawa: World Leisure and Recreation Association.

de Grazia, S. (1964). Of time, work, and leisure. New York: Doubleday.

Dixon, J.E.G. (1985). In the schools: Recreology? - Recreology! The Idler (April/May): 29-30.

Gillis, J. (1886). Aristotle's ethics. London: Routledge.

Godbey, G. (1985). The coming cross-pollination of leisure studies and recreation and park education: A response. Journal of Leisure Research 17(2): 142-148.

Goldman, C. (1984). Place to park warm bodies. C.A.U.T. Bulletin 31(2): 2.

Goodale, T. \& Witt, P. (Eds). (1980). Recreation and leisure: Issues in an era of change. College Circle, Pennsylvania: Venture Pub.

Gruneau, R. (1983). Class, sports, and social development. Amherst, Mass.: University of Massachusetts Press.

Hall, S. \& Jefferson, T. (Eds). (1976). Resistance through rituals: Youth subcultures in Post-war Britain. London: Hutchinson.

Havighurst, R.J. (1957). The leisure activities of the middle aged. American Journal of Sociology 63: $152-162$.

Haworth, J., Parker, S. \& Roberts, J. (1982). Editorial. Leisure Studies 1(1): iii-iv.

Iso-Alhola, S.E. (1980). The social psychology of leisure and recreation. Dubuque, Iowa: Wm.C. Brown.

Kelly, J. (1987). The freedom to be: A new sociology of leisure. New York: MacMillan.

Kuhn, T. (1970). The structure of scientifique revolutions. Chicago: University of Chicago.

Neulinger, J. (1974). Psychology of leisure. Springfield, Ill.: Charles C. Thomas.

Pieper, J. (1965). Leisure: The basis of culture. London: Fontana.

Reissman, L. (1954). Class, leisure and social participation. American Sociological Review 19: 76-84.

Rojek, C. (1985). Capitalism and leisure theory. London: Tavistock.

Sessoms, H. (1984). Research issues in park and recreation education: An Overview. Leisure Sciences 6: $375-385$.

Smith, S. (1985). An alternative perspective on the nature of recreation and leisure studies. Journal of Leisure Research 17(2): 155-160.

Synnott, A. (1986). An ornithology of sociology-anthropology. Society 10(1): 5-8.

White, R.C. (1955). Social class differences in the use of leisure. American Journal of Sociology 61 : 145-150. 
